\title{
Optimized Antigen Matching - Chances and Challenges in Molecular Times
}

\author{
Christoph Gassner Franz F. Wagner \\ a Blood Transfusion Service Zürich, Swiss Red Cross (SRC), Department of Molecular Diagnostics \& Research (MOC), Schlieren, Switzerland; \\ ${ }^{b}$ DRK Blutspendedienst NSTOB, Institute Springe, Springe, Germany
}

Within the last 25 years, many different aspects of molecular typing of human blood groups have been addressed by researchers focused in this field. Specific questions, rather than final visions for applications were the prime motivator to collect piece after piece of the complex puzzle of human molecular blood group polymorphism. Beside this polymorphism by itself, the feasibility of genotyping, affected by parameters such as availability of molecular techniques, their technical and phenotype-predictable accuracy as well as economic aspects, led to applications for molecular blood group typing. Nowadays, they are commonly accepted. Or in other words, applications of blood group genotyping have evolved as conclusive combinations of thoroughly elaborated studies, but were mostly unintended in the very first beginnings.

On the other hand, matching blood groups by serology typing was probably the first and most essential application for performing successful blood transfusion. In an attempt to bring one of the youngest and one of the oldest applications in transfusion medicine together, and in order to illustrate their currently existent interactions, the articles of the present issue of TrAnsfusion Medicine and Hemotherapy were compiled under the theme 'Optimized Antigen Matching - Chances and Challenges in Molecular Times'.

For the foreseeable future, alloantibody detection in patient and donor sera will not be rivaled by molecular techniques. However, as reported by Scharberg et al. [1], even this serology-dominated domain is already impacted by molecular typing: The new tools allow a much better characterization of test cells which results in improved abilities to identify irregular antibodies by serology. Enhanced donor typing is an irreplaceable prerequisite to improve matching and, thereby, to better serve the patient. Besides a few positive exceptions, many proof-of-principles and announcements with respect to donor high-throughput blood group genotyping have been reported, but reports on factually performed large-scale approaches are rare [1]. In this issue, Wagner et al. [3] are reporting on their experiences with extended donor genotyping in more than 100,000 donors by pooled capillary electrophoresis and its impact in a routine setting. Gassner et al. [4] report about a highthroughput blood group genotyping application performed in more than 37,000 Swiss blood donors, in an intention to identify homozygous carriers of low-frequency blood group antigens, e.g. rare and exceedingly rare donors.

Due to their need for chronic blood transfusions, patients suffering from sickle cell disease (SCD) or thalassemia might profit most for 'best matched' red blood cell transfusions. Next-generation or massive parallel sequencing have proven the principle for blood group determination in such patients, but are still under further development and therefore not addressed within this issue [5-7]. Based on their everyday experiences, however, Castilho and Dinardo [8] are reporting on the 'Brazilian Way', and Floch et al. [9] on the 'French Strategy' to support SCD patients by best matching strategies and the meaning of blood group genotyping in this context. Optimal strategies depend on the allelic background present; in this respect Shao et al. [10] present molecular data on RHCE alleles in Chinese and derive conclusions for the transfusion support of Chinese $\beta$-thalassemia patients. For all these patients, best matching extends beyond antigens only to the point of taking into account the ethnical origin of donor blood, thus 'ethnical matching'. Accordingly, Khan and Delaney [11] are addressing transfusion support of patients from minority population groups within this special issue.

With molecular typing, we have the chance to improve matching, and contributors to this issue demonstrate how chances were taken and challenges have been overcome for different populations. In summary, and guided by the ever intent for 'best matching', it may be concluded that current molecular blood group typing applications have become a given reality.

\section{KARGER}

(c) 2018 S. Karger GmbH, Freiburg

Fax +497614520714
Dr. Christoph Gassner 


\section{Acknowledgment}

We thank Catherine A. Hyland, Division of Clinical Services and Research, Australian Red Cross Blood Service, Brisbane, QLD 4059, Australia, for critical reading and adding helpful comments to the editorial.

\section{Disclosure Statement}

Christoph Gassner is an employee of the Blood Transfusion Service Zurich, SRC, and acts as a consultant for inno-train GmbH, Kronberg i.T., Germany.

\section{References}

1 Scharberg E, Rink G, Portegys J, Rothenberger S, Gillhuber N, Richter E, Bugert P: The impact of using genotyped reagent red blood cells in antibody identification. Transfus Med Hemother 2018;45(4): DOI $101159 / 000491884$.

$\checkmark 2$ Flegel WA, Gottschall JL, Denomme GA. Integration of red cell genotyping into the blood supply chain: a population-based study. The Lancet Haematol 2015;2: e282-288.

3 Wagner FF, Döscher A, Bittner R, Müller T: Extended donor typing by pooled capillary electrophoresis: impact in a routine setting. Transfus Med Hemother 2018;45(4): DOI 101159/000490155.

4 Gassner C, Degenhardt F, Meyer S, Vollmert C, Trost N, Neuenschwander K, Merki Y, Portmann C, Sigurdardottir S,Gottschalk J, Zorbas A, Engström C, Amar el Dusouqui S, Waldvogel-Abramovski S, Rigal E, Tissot J-D, Tinguely C, Mauvais S, Sarraj A, Bessero D, Stalder M, Infanti L, Buser A, Sigle J, Weingand B, Castelli D, Braisch M, Thierbach J, Heer S, Schulzki T, Krawczak M, Franke A, Frey BM: Low-frequency blood group antigens in Switzerland. Transfus Med Hemother 2018;45(4): DOI 101159/000490714.
Fichou Y, Mariez M, Le Marechal C, Ferec C: The experience of extended blood group genotyping by nextgeneration sequencing (NGS): investigation of patients with sickle-cell disease. Vox Sang 2016;111:418-424.

6 Dezan MR, Ribeiro IH, Oliveira VB, Vieira JB, Gomes FC, Franco LAM, et al: RHD and RHCE genotyping by next-generation sequencing is an effective strategy to identify molecular variants within sickle cell disease patients. Blood Cells Mol Dis 2017;65:8-15.

7 Chou ST, Flanagan JM, Vege S, Luban NLC, Brown RC, Ware RE, et al: Whole-exome sequencing for RH genotyping and alloimmunization risk in children with sickle cell anemia. Blood Adv 2017;1:1414-1422.

8 Castilho L, Dinardo C: Optimized antigen-matched in sickle cell disease patients: chances and challenges in molecular times - the Brazilian way. Transfus Med Hemother 2018;45(4): DOI 101159/000490713.
Floch A, Tournamille C, Chami B, Pirenne F: Genotyping in sickle cell disease patients: the French strategy. Transfus Med Hemother 2018;45(4): DOI 101159/000490858

10 Shao C-P, Zhao C-J, Wu C-L, Xu H, Wang X-D, Wu $\mathrm{X}-\mathrm{Y}$, Yi P, Dang X-T: Rh-matched transfusion through molecular typing for $\beta$-thalassaemia patients is required and feasible in Chinese. Transfus Med Hemother 2018;45(4): DOI 101159/000489471.

11 Khan J, Delaney M: Transfusion support of minority patients: extended antigen donor typing and recruitment of minority blood donors. Transfus Med Hemother 2018;45(4): DOI 101159/000491883. 